\title{
STRESS AND COPING MECHANISM AMONG PROFESI NERS STUDENTS UNIVERSITAS KLABAT
}

\author{
Angelia Friska Tendean \\ Faculty of Nursing, Universitas Klabat, JL.Arnold Mononutu, Airmadidi Bawah, North Minahasa, 95371, Indonesia \\ E-mail: angelia.tendean@unklab.ac.id
}

\begin{abstract}
Stress is a complex problem that occurs in individual and communities, both at home, school, and workplace. Response to stress is known as coping. The study aimed to identify the level of stress and the coping mechanisms among profesi ners students, as well as the relationship between the stress and coping mechanism. A cross-sectional study with decriptive correlation design conducted among 80 students ners profession selected by non-probabililty sampling method paticularly consecutive sampling techniques. The results revealed that majority of students were mildly stressed ( $n=45 ; 56,3 \%)$, and all (100\%) reported to yiel on adaptive coping mechanism. Furthermore, stress level is statistically correlated to coping mechanism $(p=.028<.05)$, with $r$ value of -.246 indicating a weak and negative correlation, implying lower stress means increase of adaptive coping mechanism. It is recommended to faculty to initiate training session for profesi ners students ners profession to enhance the adaptive coping mechanism, stress management and supports systems improvement as the endeavor in helping stidents to effectively deal with various stressors during their educational experience.
\end{abstract}

Keywords: Coping Mechanism, Profesi Ners, Stress

\begin{abstract}
Abstrak
Stres merupakan masalah rumit yang terjadi pada masyarakat, maupun individu baik di rumah, sekolah dan tempat kerja. Respon untuk mengatasi stres dikenal dengan koping. Tujuan dari penelitian ini adalah mengidentifikasi hubungan antara tingkat stres dan mekanisme koping pada mahasiswa profesi ners di Universitas Klabat. Metodelogi yang digunakan adalah cross sectional dengan desain korelasi deskriptif, menggunakan non-probability sampling dengan teknik consecutive 80 mahasiswa. Hasil penelitian menunjukkan kebanyakan responden 56,3\% stress ringan dan $100 \%$ menggunakan mekanisme koping adaptif. Hasil uji korelasi $\mathrm{p}=0.028, \mathrm{r}=-0.246$ artinya ada hubungan yang signifikan secara statistik antara tingkat stress dan mekanisme koping mahasiswa profesi ners di Universitas Klabat dengan koefisien korelasi lemah dan negatif, yang artinya semakin rendah tingkat stress maka mekanisme koping semakin meningkat. Rekomendasi bagi fakultas untuk mengadakan pelatihan mekanisme koping adaptif untuk mahasiswa, cara menangani stress dan meningkatkan sistem pendukung yang ada untuk mengatasi stress selama pengalaman pendidikan ners.
\end{abstract}

Kata Kunci: Mahasiswa Profesi, Mekanisme Koping, Stress

\section{Introduction}

Stress is a word that occupies most conversation of today's time, regardless of the seriousness of it, that it should be avoided of to be dealt with. According to
Papanthanasiou et al (2015) stress can be defined as a reaction (consubstantial with specific changes that human biological system is experiencing) or as a 
stimulus (environmental events can be acute, chronic, remitting and continuous chronic form that cause those changes). The prevalence of stress in the world is being rather high and increasing every year. In America, about $75 \%$ adults experience stress and increase every year (American Psychological Association, 2013). Based on data from Baseline Health Research of Republic of Indonesia in 2013, from the total population of Indonesia aged 15 years and above, $6 \%$ were having mental emotional disorder, while in North Sulawesi Province the number reached 22,3\% (KEMENKES, 2013). In our daily lives, people are often faced situations that triggers stress. Nevertheless Bukhsh \& Shanhzad, 2011 mentioned the interpretation and reaction to events that create stress are different for different people. However, for young people and students, in particular stressful life events can weighed and emerge heavily on their lives. Stress is related multifactorial among profesi ners students, it is arising from both academic and non-academic factors included stress through caring of patients, assignment and workloads, negative interaction with staff and faculty (Monteiro \& Balogun, 2014 ;Brand \& Schoonheim-Klein, 2009; Labrague, 2017)

Stress causes adverse reaction through interaction between stressors and individual perceptions of and reaction to these stressors. The body's response to stress can affected various pathological and disease due to various factor such as hormones, neuroendocrine mediators, peptides and neurotransmitters (Yaribeygi, et.al, 2017). Individual with too much stress or chronic stress can affect physical and mental health and it increases risk of premature mortality (Al-Dubai, Al-Naggar \& Rampal, 2011). In addition, Tse J (2010) stated that stress also causes Anxiety, and other negative emotions and feelings such as press, pain, sadness, depressed etc., and the serious problem is Psychological disorder such as Post-traumatic stress disorder (PTSD).

When one exposed to stress, the response to it is termed as coping mechanism. Coping is process to manage which is external or internal demands, that are perceived as taxing on personal capabilities and resources (Bamuhair, et.al 2015). Every people has a coping mechanism that have variation depending on the level of stress and problem experience. There are two types of coping mechanism, in which the first is problem-focused coping that efforts are made to change the stressful situations through solving, decision making and direct action and while the second is emotion-focused coping that attempts are made to regulate distressing emotion, sometimes by changing the meaning of stressful situation cognitively without actually changing situation (Bagqutayan, 2015). Individual who tries to change their problems with focusing efforts on task or approach their emotions through acceptance may have better psychological and physical outcomes than those who try to avoid problems by giving up or disengaging or emotion through distraction. Many studies have reported that problem focused coping is associated with better psychological outcomes which are ameliorate downstream minor stressor without affecting the focal stressors or helps people feel more in control regardless of the actual efficacy of their coping efforts (Segerstrom \& O’Connor, 2012).

Coping is important for human survival of stressor. Researchers have found that stress level in students have relation with coping mechanism. According to Suminarsis and Sudaryanto (2017), there are 67\% students has adaptive coping mechanism and 43\% has maladaptive coping mechanism, with $p$ value $=0.001$. Another research show there are $54.8 \%$ students has coping maladaptive and $45.2 \%$ students has severe stress with $p$ value $=0.000$ (Dahlia, 2017). According to Anelia (2012) the higher level of stress experienced will make someone has lower coping mechanism. Having a higher number of positive coping strategies availableinn dealing with strees that can give edividual more resources to deal with stress. This allows invidual to manage stress more effevtively and be more confident to face problems (Heffer, 2017).

Studies on stress and coping mechanism among students in North Sulawesi are few and far in between. The objectives of this study were to identify the level of stress and the coping mechanism of pfrofesi ners students and further to the determine correlations between stress and coping mechanism.

\section{Method}

Methodelogy in this study is cross-sectional study with descriptive correlation design which is to find out the relation between stress level and coping mechanism among profesi ners students Universitas Klabat. Univariate analysis described in frequency and persentage, while bivariate employed pearson's correlation as statitical treatment.

Population is overall limited or unit informal that prople want to study with limitations content, scope 
and time. The population in this study were profesi ners students first and second semester at Universitas Klabat. Samples are part of an affordable population that can used as the subject of research through sampling (Nursalam, 2017). The sample in this study was drawn using probalilty sampling method with simple randoms sampling technique.

The measurement of the variables in the study, a valid and realiable quetionnaire consisting of 13 stress-related items and 19 to measure coping mechanism adopted and obtained a permission to be used from Anelia (2012) with cronbach's alfa of 0.835 and 0.706 for stress and coping mechanisms respectively and it categorized as scores between 0 25 are mild stress, 26-39 are moderate stress and 4056 are severe stress, and for coping which are scores 0-38 are maladaptive coping mechanism and 39-76 are adaptive coping mechanism.

\section{RESULTS}

\section{Demographic Data}

Stress and coping mechanism were observed in 80 respondents. Tabel 1 contains the descriptive of respondents while 14 were male, acounted for $17.5 \%$ and the majority were female 66 respondents $82.5 \%$. Most participants $(n=51,63.8 \%)$ lived at boarding house, and according to seniority, $40 \%(\mathrm{n}=32)$ were seniors and the other $60 \%(n=48)$ were juniors.

\section{Tabel 1. Demographics Data}

\begin{tabular}{clll}
\hline No & Data & Frequency & $\mathbf{( \% )}$ \\
\hline 1 & Gender & & \\
& Male & 14 & 17.5 \\
& Female & 66 & 82.5 \\
2 & Housing & & \\
& Boarding House & 51 & 63.8 \\
& Parents & 19 & 23.8 \\
& Dormitory & 1 & 1.3 \\
& Others & 9 & 11.3 \\
3 & Class & & \\
& Junior & 32 & 40 \\
& Senior & 48 & 60 \\
\hline
\end{tabular}

\section{Level of stress}

Results of the stress level can be shown at Tabel 2 . While that shows there were 45 respondents $(56.3 \%)$ in mild stress, moderate stress $(n=35 ; 43.8 \%)$ and there was no students in severe stress.
Tabel 2. Distribution level of stress among students ners profession

\begin{tabular}{|c|c|c|c|}
\hline No & Stress Level & Frequency & $(\%)$ \\
\hline \multirow[t]{2}{*}{1} & Mild & 45 & 56.3 \\
\hline & & & 43.8 \\
\hline \multicolumn{2}{|c|}{$\begin{array}{l}\text { Continued...... } \\
\text { Tabel } 1 \ldots \ldots \ldots .\end{array}$} & 35 & \\
\hline \multirow[t]{2}{*}{3} & Severe & 0 & 0 \\
\hline & Total & 80 & 100.0 \\
\hline
\end{tabular}

\section{Coping mechanism}

Tabel 3 shows that all 80 respondents (100\%) have adaptive coping mechanism.

Table 3. Distribution of coping mechanism among students ners profession

\begin{tabular}{llll}
\hline No & $\begin{array}{l}\text { Coping } \\
\text { Mechanisms }\end{array}$ & Frequency & $\mathbf{( \% )}$ \\
\hline 1 & Adaptive & 80 & 100 \\
2 & Maladaptive & 0 & 0 \\
\hline & Total & 80 & 100.0 \\
\hline
\end{tabular}

Relationship between stress and coping mechanism

The results on tabel 4 shows p-value of $0.028<0.05$. That's sygnigying corellation between stress level and coping mechanism among prosesi ners students at Universitas Klabat. Coeficient correlation shows the $r$ value of -.246 indicating a weak and negative orrelation between stress and coping mechanism sygnigying that lower stress means increase coping mehanism.

Tabel 4. Relationship between stress level and coping mechanism among students ners profession

\begin{tabular}{llll}
\hline & & stress & coping \\
\hline stress & Pearson & 1 & $-.246^{*}$ \\
& Correlation & & \\
& Sig. (2-tailed) & & .028 \\
& $\mathrm{~N}$ & 80 & 80 \\
\hline coping & Pearson & $-.246^{*}$ & 1 \\
& Correlation & & \\
& Sig. (2-tailed) & .028 & \\
& $\mathrm{~N}$ & 80 & 80 \\
\hline
\end{tabular}




\section{DISCUSSION}

Stress can be rated as mild, moderate and severe (McMahon, 2011). The result showed there was $56.3 \%$ respondents have mild stress. According to Silverman, et.al. (2010) stress is a bodily reaction to change which needs response, regulation and /or physical, psychological, and or emotional adaptation and it be derived from any situation, condition, thought, and/or stat, just need to cause frustration, anger, nervousness and or anxiety. Stress is affecting any individual regardless of their developmental stage, no exceptional students (Reddy, Menon \& AnjanaThattil 2018). Sources stress among Nursing students include assignment and workload, teacher and graduate, peers and daily life and taking care of patients (Shdaifat, Jamama, \& Al-Amer, 2018). Kadapatti and Vijayalaxmi (2011) explained stress affected most student's academic performance and become a grave reality as a career stopper. Additionally, stress may induce both beneficial and harmful effects. Harmful effects can affected various pathological and disease due to various factor such as hormones, neuroendocrine mediators, peptides and neurotransmitters are involved in the body's response to stress (Yaribeygi, et.al, 2017).

Coping mechanism is a reaction to stressful experience. The result showed there were 80 respondents $(100 \%)$ using coping adaptive mechanism. Using adaptive coping mechanism in daily live is most important for human body. The benefits are helping functions of human. There are growth, integration, learning and achieving goals. It's effectively usable when talking to other people, problem solving, relaxation techniques, balance exercise and activities, while maladaptive coping is not a goood mechanism because it inhibits the function of integration, growth breaks down, decrease autonomy and tends the environment such as eating excessive or not eating, overworking, avoiding people (Anelia, 2012). Adaptive coping is a healty coping to disturb or activate stressful encounters environment. It's not only emotionally, but requires the simultaneous coordination of physiology, attention behavior, motivation and cognition (Skinner \& Zim mer-Gembeck, 2016).

Theoretically, people can manage their stress with coping mechanism. Field, McCabe and Schneiderman (2013) explained about the psychophysiological responses in adaptive coping. There is through the Sympathetic Adrenomedullary (SAM) system that is increasing metabolic activity in response to situations perceived as being stressful. However, other system such as Hypothalamic Pituitary Adrenocortical (HPAC) systems may play some roles in psychophysiological of adaptive coping by acting synergistically with the SAM system. For instance, in emergency situations, the glucocorticoids cause the rapid mobilization of amino acids and fats from cellular store and these become available directly as an energy sources for the synthesis of energy rich glucose, also endogenous opiate system may play a role by reducing fear, inhibiting pain related withdrawal behaviors and providing analgesia during fighting and other coping reactions.

The results showed there was statistically significant correlation between stress and coping mechanisme among students ners profession at Universitas Klabat with $p$ value of $0.028<0.05$, and $r$ value of -0.246 . Other researchers also found there was correlation between stress and coping mechanism (Anelia, 2012.;Dahlia, 2017; Mulyani, Evi and Ulfah, 2017; Suminarsis \& Sudaryanto, 2017). According to Anelia (2012) and Suminarsis and Sudaryanto (2017) the higher level of affecting coping mechanism making the people tend adopt maladaptive coping mechanism. Adaptive coping mechanism is a healthy coping that can reduce stress level (Niedzwiecki, Pepper and Weaver, 2019).

\section{CONCLUSION}

The findings of this study led to the concludion that the majority profesi ners students experinced mild stress and all students have adaptive coping mechanism and there was significant correlation between stress and coping mechanism. People with stress can use adaptive coping mechanism as a good coping mechanism. Severe stress or prolonged will impact in our body, induce many disorders or diseases. It is recommended to strenghten the student;s coping mechanism by initiating training sessions on stress management with adaptive coping mechanism and improving peer group supports to manage their stress on their educational experienced. Furthermore, future researchers might conduct studies to identify the factors associated with coping mechanisms.

\section{REFERENCES}

Al-Dubai, S. A.-N. (2011). Stress and coping strategies of students in a Medical Faculty in Malaysia. Malyasian Journal of Medical Sciences, 18(3), 57-64. 
American Psychological Association. (2013). Americal Psychological Association. Retrieved February 4, 2019, from Americal Psychological Association: http://www.apa.org/news/press/releases/stres s/2012/full-report.pdf.

Bamuhair, S., Al Farhan, A., Althubaiti, A., Agha, S., Rahman, S., \& Ibrahim, N. (2015). Sources of stress and coping strategies among undergraduate medical students enrolled in a problem-based learning curriculum. Jornal of biomedical education., Vol.2015, 18.doi:http://dx.doi.org/10.1155/2015/575139

Brand, H., \& Schoonheim-Klein, M. (2009). Is the OSCE more stressful? Examination anxiety and it's consequences in different assessment mehods in dental education. European Journal of Dental Education Vol.13, 147-153.

Bukhsh, Q., \& Shanhzad, A. A. (2011 ). A Study of Learning Stress and stress management strategies of the student postgraduate level: A case study of islamia university of Bahawalpur, Pakista. Journal Procedia Social and behavioral sciences, 182-186.

Field, T, McCabe, P\& Scheinerman.(2013). Stress and coping. Ney Jersey: Lawrence Erlbaum Associates.

Kemenkes RI.(2013). Riset Kesehatan Dasar;RISKESDAS. Jakarta: Kemenkes RI.

Labrague, L. (2017). A literature review on stress and coping strategies in nursing students. Journal of mental health.Vol.6.Issue 5, 471480.

McMahon, G. (2011). No more stress. London: Karnac Ltd.

Monteiro, N. M., \& Balogun, S. K. (2014). Managing stress: the influence of gender, age and emotion regulation on coping among university students in botswana. International Jurnal of Adolescence and Youth.Vol.19.No.2, 153-173.
Mulyani, Y. E., Evi, R.M., and Ulfah, Littia (2017). Hubungan mekanisme koping dengan stress kerja perawat IGD dan ICU di RSUD Ulin Banjarmasin. AL-ULUM:Journal Ilmu Sosial dan Humaniora, Vol.3, No.2, p.513524.

Niedzwiecki, B., Pepper, J.,\& Weaver, P.A.(2019). Kinn's Medical Assisting Fundamentals.Missouri: Elsevier.

Nursalam, E.F.(2017). Metodologi penelilitian ilmu keperawatan. Jakarta: Salemba Medika.

Papanthanasiou, I.V., Tsaras, K., Neroliatsiou, A., Roupa, A.(2015). Stress:concepts, theoritical models and nursing interventions. American Journal of Nursing Science. Vol.4, No.2-1, 45-50.

Doi: 10.11g48/j.ajns.s.2015040201.19.

Reddy, K. M. (2018). Academic stress and its sources among University Students. Biomedical and Pharmacological Journal, Vol.11 (1).,doi:http://dx.doi.org/10.13005/bpj/1404.

Shdaifat, E., Jamama, A., \& Al-Amer, M. (2018). Stress and Coping Strategies among Nursing Students. Global Journal of Health Science, .Vol.10,No.5,33-41.

Silverman, M. e. (2010.Vol.2). Nueroendocrine and immune contibutors to fatigue. $P M \& R$, 338-346.

Skinner, E. A., and Zimmer-Gembeck. (2016). The development of coping. Switzerland: Springer.

Tse J, F. R. (2010). Facets of job effort in bus driver health: deconstructing effort in the effortreward imbalance model. Journal of Occupational Health Psychology.Vol.12, 4862 '

Yaribeygi, H., Panahi, Y., Sahraei, H., Johnston, T.P., and Sahebkar, A. (2017). The impact of stress on body function: A review. EXCLI Journal. Vol.16, p.1057-1072. doi:10.17179/excli2017-480. 